\title{
喉頭白色病変の臨床および病理組織学的研究
}

\author{
高橋 裕子, 吉原 俊 雄 \\ 高山幹子, 石井哲夫
}

\section{A Clinicopathological Study of White Lesions in the Larynx}

\author{
Yuko Takahashi, M.D., Toshio Yoshihara, M.D., \\ Mikiko Takayama, M.D., and Tetsuo Ishii, M.D. \\ Department of Otolaryngology, Tokyo Women's Medical College, Tokyo
}

\begin{abstract}
White lesions of the larynx should be diagnosed and treated carefully from the clinical and pathological point of view. Fifty-three patients with white lesions of the larynx who were not diagnosed as having carcinoma were treated surgically in our hospital between 1986 and 1993. The ratio of males to females was $7.8: 1$, with most patient in their fifties. About $70 \%$ of the patients were smokers and $86 \%$ were drinkers. $90 \%$ had lesions in the vocal cords, equally on both sides. All of the patients were treated by laryngomicrosurgery under general anesthesia and examined pathologically. Seventeen cases (32\%) displayed dysplasia and two cases $(3.8 \%)$ showed a malignant change. White lesions of the larynx should, therefore, be regularly checked and re-biopsies undertaken when necessary.
\end{abstract}

Key words : 喉頭白色病変, 病的角化, dysplasia, 癌化

\section{I .はじめに}

喉頭白色病変は, 臨床的には白斑症, 角化症, ロイコプラキーなどと呼ばれ, 病理組織学的に は病的角化の程度や異形成所見 (dysplasia) の 有無など, 診断医により表現方法は多種多様で 統一されていない。よってその診断の受けとめ 方, 今後の治療の方針など, 苦慮することが多 い疾患でもある。

今回われわれは, 当教室で経験した喉頭白色 病変について, 臨床および病理組織学的に検討 を加えたので，ここに報告する。

\section{II. 対 象}

対象は, 1986年 1 月から1993年12月までの 8

東京女子医科大学耳鼻咽喉科学教室

別刷請求： $=162$ 東京都新宿区河田町8-1

東京女子医科大学耳鼻咽喉科 高橋裕子

投稿受付：1996年 1 月30日
年間に，当教室でラリンゴマイクロサージャリ 一を施行し, 初回病理組織検査で喉頭癌および carcinoma in situ と診断されたものを除く喉 頭白色病変の53例について, 臨床および病理組 織学的検討を行った。

\section{III. 結 果}

\section{1. 性別および年觜}

男性 47 例, 女性 6 例の計53例で, 男女比は7.8 対 1 だった。年齢は30歳から74歳までの平均 $54.0 \pm 11.2$ 歳で, 男性は50歳代と60歳代がもっ とも多く, ついで40歳代が続き, 女性は50歳代 が最も多かった（図 1)。

\section{2. 主訴および病悩期間}

主訴は嗄声が最も多く, 咽喉頭違和感, 咽頭 痛と続くが, 異常な呼吸音, 鼻閉, 自覚なしな ど，咽頭の異常は自覚されずに偶然喉頭白色病 変が発見された症例もあった（表 1 )。

病悩期間は 1 力月以内が約 3 割, 3 力月以内 


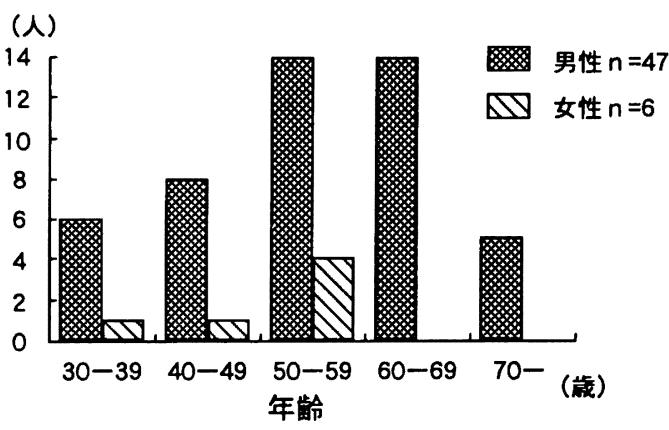

図 1 性別および年齢

表 1 主訴(一部重複）（ $\mathrm{n}=53 ）$

\begin{tabular}{|c|c|c|}
\hline 声 & 42例 & $(76.4 \%)$ \\
\hline 咽喉頭違和感 & 7 & $(12.7)$ \\
\hline 咽 頭 痛 & 3 & $(5.5)$ \\
\hline 異常な呼吸音 & 1 & $(1.8)$ \\
\hline 鼻＼cjkstart閉 & 1 & $(1.8)$ \\
\hline 自覚なし & 1 & $(1.8)$ \\
\hline
\end{tabular}

表 2 病悩期間（n=53）

\begin{tabular}{|c|c|c|}
\hline$\sim 1$ 力月 & 15例 & $(28.3 \%$ \\
\hline$\sim 3$ 力月 & 19 & $(35.8)$ \\
\hline$\sim 6$ 力月 & 8 & $(15.1$ \\
\hline 6 力月～ & 8 & $(15.1)$ \\
\hline な し & 3 & $(5.7)$ \\
\hline
\end{tabular}

で 6 割を超すが，なかには 10 年たっている例も あった（表 2 )。

\section{3. 嗜好}

喫煙歴のある例は37例，ない例は16例で， Brinkman 指数が 400 未満は 10 例，400以上は 27

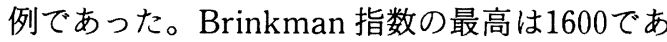
った。アルコール歴のある例は46例で，ない例 は 7 例であった（表 3 )。

\section{4 . 病変部位}

患側は, 右側 17 例, 左側 24 例, 両側が12例だ った。部位別では声帯が最も多く，仮声帯と後 交連は各 2 例，披裂部は 1 例であった。声帯の 内訳は，多い順に声帯前方 $1 / 3$, 後方 $1 / 3$, 中央 $1 / 3$ ，前中 $1 / 3$ にたがる例，全長にわたるもの であった（表 4 )。

\section{5 . 病理組織学的所見}

初回病理組織検査は全例全身麻酔下でラリン ゴマイクロサージャリーが施行された。採取組
表 3 嗜好 $(n=53)$

\begin{tabular}{|c|c|c|}
\hline \multicolumn{3}{|c|}{ 1. 鿄煙歴 } \\
\hline & あり & 37例（69.8\%） \\
\hline \multicolumn{3}{|c|}{ Brinkman 指数（タバコ本数/日×年） } \\
\hline & $\sim 399$ & 10例（18.9\%） \\
\hline & $400 \sim$ & 27例（50.9\%） \\
\hline & なし & 16 例 $(30.2 \%)$ \\
\hline 2 & \multicolumn{2}{|c|}{ アルコール歴 } \\
\hline & あり & 46 例 $(86.8 \%)$ \\
\hline & なし & 7例（13.2\%） \\
\hline
\end{tabular}

表 4 病変部位 $(n=53)$

\begin{tabular}{llll}
\hline 1 . 患側 & 右側 & 17 例 & $(32.1 \%)$ \\
& 左側 & 24 & $(45.3 \quad)$ \\
& 両側 & 12 & $(22.6)$ \\
2. 部位 & 声帯 & 48 例 & $(90.5 \%)$ \\
& 前方 $1 / 3$ & 18 例 \\
& 前中 $1 / 3$ & 6 \\
& 中央 $1 / 3$ & 9 \\
& 後方 $1 / 3$ & 12 \\
& 全体 & 3 \\
& 仮声帯 & 2 例 & $(3.8 \%)$ \\
& 後交連 & 2 & $(3.8)$ \\
& 披裂部 & $(1.9)$ \\
\hline
\end{tabular}

表 5 病理組織学的所見 $(n=53)$

\begin{tabular}{lcc}
\hline 病的角化所見 & 重複あり & \\
hyperkeratosis & 18 例 & \\
parakeratosis & 9 & \\
dyskeratosis & 8 & \\
acanthosis & 32 & \\
basal/parabasal cell の增生 & 14 & \\
異形成 (dysplasia) 所見 & & \\
dysplasia なし & 36 例 & $(68.0 \%)$ \\
mild dysplasia & 8 & $(15.1)$ \\
moderate dysplasia & 4 & $(7.5)$ \\
severe dysplasia & 5 & $(9.4)$ \\
\hline
\end{tabular}

織片をホルマリン固定し，ヘマトキシリンーエ オジン染色した標本について光学顕微鏡下に検 討した。病的角化所見については, hyperkeratosis 18例, parakeratosis 9 例, dysperatosis 8 例, acanthosis 32例, basal/parabasal cell の 増生14例と，種々の結果が得られた。また異形 成 (dysplasia) 所見からは，所見なし36例, mild 


初回ope $\quad 1$ 年 $\quad$\begin{tabular}{c} 
\laryngomicrosurgery \\
$* \mathrm{CO}_{2}$ laser \\
\hline
\end{tabular}
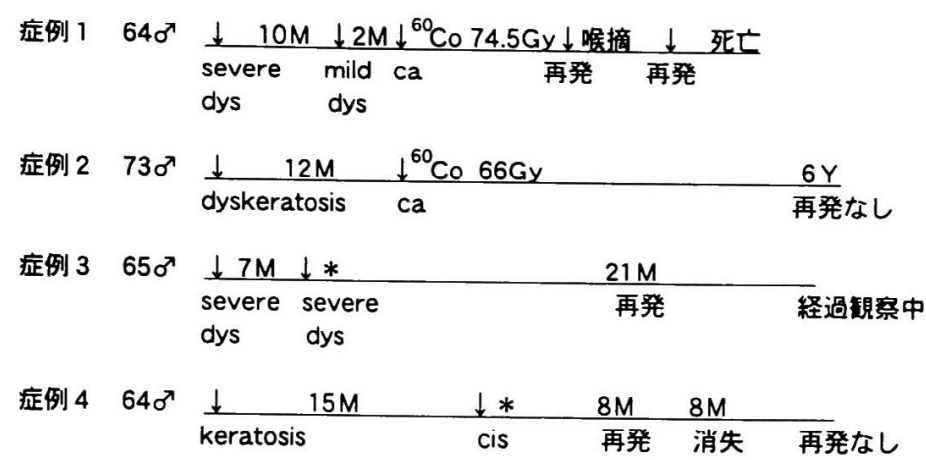

図 2 再発例と臨床経過について (cis：carcinoma in situ)

dysplasia 8 例, moderate dysplasia 4 例, severe dysplasia 5 例であった（表 5 )。

\section{6 . 治 療}

喉頭白色病変は，当科では原則的に全身麻酔 下にラリンゴマイクロサージャリーを施行して いる。ここ数年は術中に迅速病理組織検査を行 い，結果によりただちに炭酸ガスレーザーで焼 灼する症例も増加してきている。しかし迅速病 理組織検査に提出可能な大きさの組織が採取で きない場合や，迅速病理組織検査の結果とホル マリン固定標本での組織検査の結果が異なるこ ともあり，ルーチン化した方法ではない。また 初回は組織採取のみで再発した症例で, 迅速病 理組織検査で喉頭癌と診断されなかった場合に は，炭酸ガスレーザー焼灼が施行されている。

\section{7. 再発症例}

再発した症例は53例中20例あり，このうち再 発非癌化例は18例, 再発癌化例は 2 例であった。 これらの症例の一部の経過を提示する（図 2 )。 症例 1 は, 64歳男性で嗄声を主訴に他院を受 診し精查を受け，ロイコプラキーと診断された ため当科を紹介された症例である。初診は1992 年 7 月 4 日で, 左声帯前方 $1 / 3$ にやや隆起した白 色病変を認めたが,声帯の可動性は正常だった。 7 月20日全麻下でラリンゴマイクロサージャリ 一を施行し，前交連には病変がかかっていない ことを確認し,白色部も含めて切除した(図 3 )。 初回病理組織は basal/parabasal cell $の$ 肥

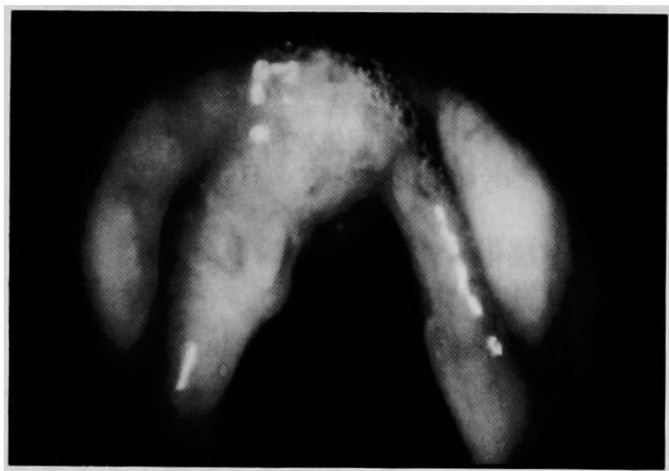

図3 症例 1 の初回ラリンゴマイクロサージャリー の術中写真

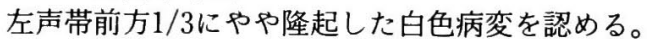

厚，延長を特徵とする severe dysplasia だった (図 4 )。10力月後外来経過中に同部に再発を認 め, 組織検査で mild dysplasia（図 5 ）だった が,さらにその 2 力月後肉眼的に急速に発育し, 軽度呼吸困難も伴ってきたため, 緊急入院, 気 管切開後再組織検査を行い, squamous cell carcinoma と診断された（図 6 )。

${ }^{60} \mathrm{Co}$ を $74.5 \mathrm{~Gy}$ 照射したが，照射終了後より 続く仮声帯の腫脹がさらに著明になった 8 力月 後再発を確認し, 喉頭全摘出術を行った。しか し, 術後 5 力月で気切口から気管分岐部に至る 気管内に再発し, 死亡した。初回，2 回目の組 織を再検討したが，いずれの組織も癌とするに は所見がそしいとの病理医の診断も得て, 白色 


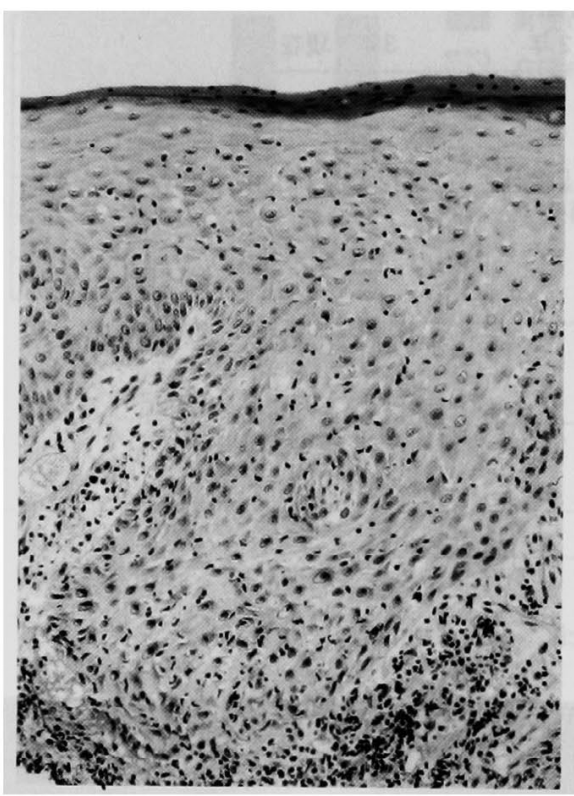

図 4 症例 1 の初回生検病理組織所見 severe dysplasia を示す $(\mathrm{H}-\mathrm{E}, \times 200)$ 。

病変部が癌化したものと結論した。

症例 2 は, 73歳男性で, 嗄声を主訴に受診し た。初回病理組織検査で dyskeratosis と診断さ れ，12力月後に再発して squamous cell carcinoma と診断され, ${ }^{60} \mathrm{Co}$ を $66 \mathrm{~Gy}$ 照射した。6 年後の現在再発は認められない。

症例 3 は65歳男性で, 嗄声を主訴に受診した。 右声帯前方 $1 / 3$ に隆起した白色病变を認め（図 7 ), 初回病理検査で severe dysplasia と診断 された。 7 力月後再発し, 再検査にて同様に severe dysplasia であったため, 炭酸ガスレー ザーで焼灼した。21力月後, 病変部位の白色変 化が認められるものの現在経過観察中である。 症例 4 は64歳男性で, 鼻閉を主訴に受診し, 偶然に左声帯中央 $1 / 3$ に平坦な白色病変を指摘 された (図 8 )。初回病理検査で keratosis と診 断されたが，15力月後再発したため再検査を施 行し, carcinoma in situ (図 9 ) と診断され, 炭酸ガスレーザーで焼灼した。その 8 力月後に 再発し, 検査を予定していたが肉眼上, 自然消 失し現在㛜重に経過観察中である。

以上 4 例も含めた再発症例は, いずれも Brinkman 指数が 400 以上の症例で, 術後の禁煙

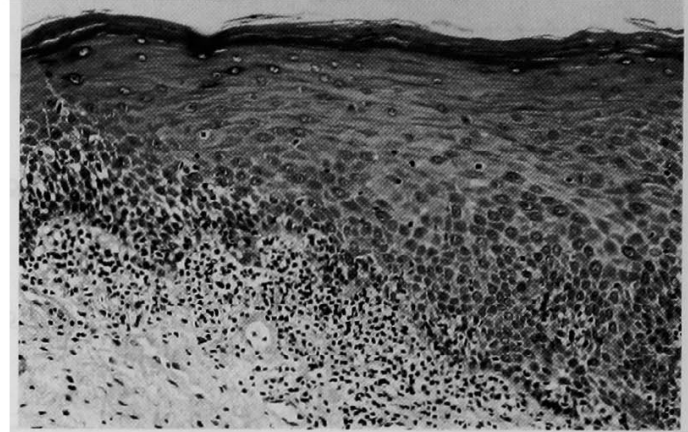

図 5 症例 1 の 2 回目生検の病理組織所見 mild dysplasia を示す $(\mathrm{H}-\mathrm{E}, \times 200)$ 。

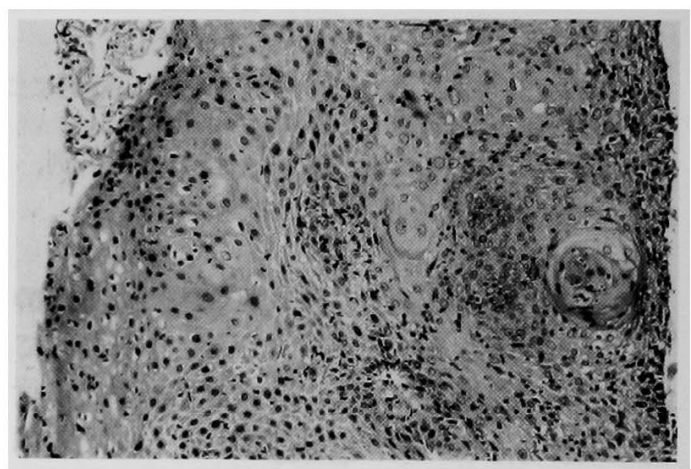

図 6 症例 1 の 3 回目生検の病理組織所見 squamous cell carcinoma と診断される $(\mathrm{H}-\mathrm{E}, \times 200)$ 。

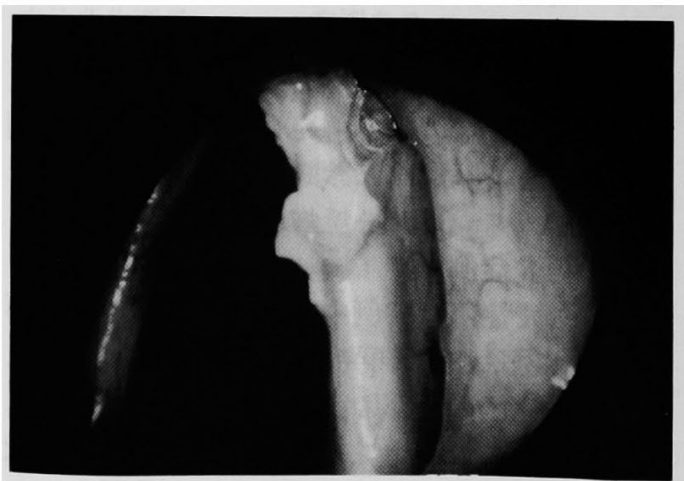

図 7 症例 3 の初回ラリンゴマイクロサージャリー の術中所見

右声帯前方 $1 / 3$ に隆起した白色病変を認める。

が守られていなかった。

\section{IV. 考察}

喉頭白色病変とは, 臨床的にはロイコプラキ 


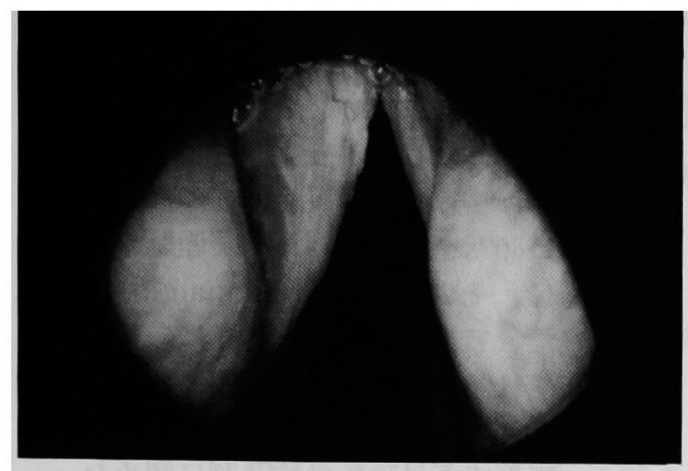

図 8 症例 4 の初回ラリンゴマイクロサージャリー の術中所見

左声帯中央 $1 / 3$ に平坦な白色病変を認める。

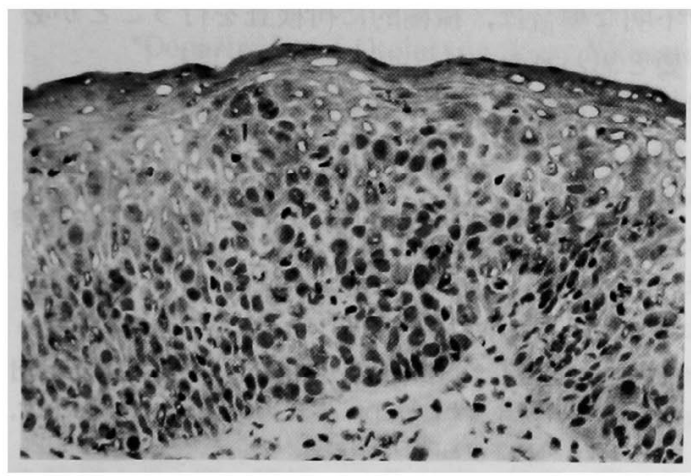

図 9 症例 4 の 2 回目生検の病理組織所見 carcinoma in situ と診断される $(\mathrm{H}-\mathrm{E}, \times 400)$ 。

一, 喉頭角化症, 喉頭硬皮症 (pachydermia) な どと呼ばれているが, 病理組織学的には喉頭過 形成症（epithelial hyperplasia）として取り扱 われている。さらに, 一部の症例では癌化する こともあり，その取扱いは慎重に行われている。 しかし, 病理所見に対する診断の多樣性や, 癌 化の可能性を強く示す表現など，治療方針に苦 慮する症例も少なからず経験する。

epithelial hyperplasiaに共通する病理学的 所見について, Barnes ${ }^{1)}$ は14項目の病理所見を あげ, またその中でも悪性化する可能性の高い 特徵的な所見もあげている。

進ら 21 は, epithelial hyperplasia の病理組織 学的分類を試み, 臨床に即したわかりやすい分 類として hyperplasia without atypia, dysplasia, carcinoma の 3 つに分類し, 提唱してい る(表 6 )。この分類法に従って検討された研究
表 6 Epithelial Hyperplasia の病理組織学的分類 (進らの分類 ${ }^{21}$ より引用)

1. Hyperplasia without atypia

a . without basal cell hyperplasia

b . with basal cell hyperplasia

2. Dysplasia
a . low grade
b. high grade

3. Carcinoma
a . carcinoma in situ
b. invasive carcinoma

も多い。しかし各施設の病理医によって組織学 的基準が多少とも異なることがあり，臨床医と 病理医との統一見解は提示されて抢らず，いま だに課題の残されている疾患概念といえる。

治療法であるが，保存的治療については音声 治療, 吸入療法, 薬物療法, 禁煙が一般的に行 われている。これは保存的治療により白色病変 あるいは随伴する炎症などがある程度軽快する 例があるからである2!。

佐藤ら ${ }^{3)}$ は, 病変が軽度であれば経過観察を 行いながら保存的治療を行えば，約半数の病変 は治癒し，さらに喫煙者には禁煙を指導するこ とにより治癒率は高まり, 観察期間は 2 力月を 目安として, 病変に変化のない例は手術的治療 を考えると報告している。

中之坊ら ${ }^{4)}$ は白色病変周囲に炎症所見を認 め, 病変も比較的小さいものが適応であるとし, 保存的治療に反応しない例や異形成所見の見ら れる例では積極的に手術療法を行うべきだと述 べている。

手術的治療については, 原則的に全身麻酔下 にラリンゴマイクロサージャリーを施行し, 症 例により炭酸ガスレーザー焼灼術が施行されて いる 2 4)。生検はメスで上皮の基底層を含めて 切除した後, 声帯勒帯が露出する梁さまでレー ザーで蒸散することが薦められている。

レーザー焼灼の長所は, 出血を減らし, 癌組 織の播腫を防止することが可能である ${ }^{5)}$, 音声 学的には術後の声帯振動への影響が軽度であ る6) と報告されている。短所については, 術後 白苔の付着が起こり，炎症所見の残存を様々な 程度で認めながら約 1 力月前後で消失するが, 
日気食会報，47（4），1996

表 7 喉頭白色病変（癌を含まず）の癌化率 (本邦報告例)

\begin{tabular}{llrl}
\hline 藤巻ら $^{7)}$ & $(1971)$ & $3.3 \%$ & $(1 / 30$ 例 $)$ \\
小林 $^{8)}$ & $(1977)$ & $11.8 \%$ & $(4 / 34)$ \\
中之坊ら $^{4)}$ & $(1991)$ & $5.9 \%$ & $(3 / 51 \quad)$ \\
佐藤ら $^{3)}$ & $(1993)$ & $7.7 \%$ & $(7 / 91 \quad)$ \\
自験例 $^{3}$ & $(1993)$ & $3.8 \%$ & $(2 / 53 \quad)$ \\
\hline
\end{tabular}

声帯の部分的あるいは全体的な萎縮を残す例も 中にはある6)という報告もある。

今回のわれわれの症例は, 全例全身麻酔下で のラリンゴマイクロサージャリーを施行し, 症 例によりレーザー焼灼を行った。レーザー焼灼 を行った例は術後数力月にわたり, 局所に白苔 が付着するために再発かどうかの判断に迷った 症例もあった。再発を疑った場合には,レーザ 一手術後の局所判定の難しさもあるので, 積極 的な再検査を考えなくてはならない。

喉頭白色病変の癌化率について過去の報告を 表 7 にまとめた茾, 7,8)。ここでは白色病変の中に 癌は含まれていない。ばらつきはあるものの 10 \%前後である。ちなみに白色病変の中に癌が含 まれている統計では，進ら 21 は20\% (7/35例)， 都ら 91 は7.7\% (7/91例) であった。自験例では, 癌化症例は 53 例中 2 例 $3.8 \%$ であった。短期間 の生検で癌を発見した場合に, 短期間で癌化し たと考えるか，あるいは初期より癌とそうでな い病変が混在していて，偶然癌でない部位を採 取していたのかは疑問である。松村ら ${ }^{10}$ は, mild dysplasia は短期間で癌化することはない が, moderate および severe dysplasia では厳 重経過観察, 再検を要し, 特に severe dysplasia では para cancerの可能性もあると述べてい る。

喉頭白色病変では, 定期的な診察と, 積極的 な組織の再検査とともに，患者自身への啓蒙も 必要であると思われた。

\section{V.まとめ}

1986年 1 月から1993年12月までの 8 年間に, 東京女子医科大学耳鼻咽喉科でラリンゴマイク ロサージャリーを施行し, 初回病理組織検査で 喉頭癌および carcinoma in situ と診断された ものを除く喉頭白色病変の53例（男性47例, 女
性 6 例) について，臨床および病理組織学的検 討を行った。

1）男女比は7.8対 1 で, 男性は50,60歳代に, 女性は50歳代に最も多かった。

2 ) 主訴は嗄声が最も多く，3 力月以内に受 診したのは $60 \%$ を超えていた。喫煙歴のあるの

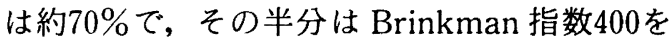
超えていた。アルコール歴は $86 \%$ にあった。

3 ) 病変は $90 \%$ は声帯で, 患側に左右差はな かった。初回病理検査では種々の病的角化所見 を認め, 異形成所見はその約 3 割に認めた。

4 ) 初回組織検査の際, 組織の切除のみでな く炭酸ガスレーザー焼灼も併用するようになっ た。しかし，術後の腫脹のために再発の有無が 不明な場合は，積極的に再検査を行うことが必 要と思われた。

5 ）自験例での癌化症例は53例中 2 例 $3.8 \%$ であった。

本論文の要旨は第45回日本気管食道科学会総会 （1993年，佐賀市）において口演した。

\section{文献}

1) Barnes, L. : Surgical Pathology of the Head and Neck (vol. 1), pp.299-311, Marcel Dekker, Inc., New York, 1985.

2) 進 武幹, 平出芳生, 平野実・他：喉頭の epithelial hyperplasia一臨床的ならびに病理組 織学的研究.耳鼻臨床, $73: 767-782,1980$.

3 ）佐藤公則, 坂口伸治, 吉田哲二・他：喉頭上皮 過形成症の臨床統計と治療。耳鼻臨床, 補62： 39-46, 1993

4 ) 中之坊学, 田辺哲也, 北原 聡-他：喉頭白色 病変の臨床的検討。日気食会報，42:317-322, 1991.

5 ）松尾浩一, 進 武幹, 富田まり子・他：喉頭腫 瘍性疾患における $\mathrm{CO}_{2}$ laser による治療経験。 耳鼻, $31: 395-400,1985$.

6 ）進 武幹, 渡辺 宏, 前原法文 : 喉頭の epith elial hyperplasia. 耳鼻臨床, 82:1-11, 1989.

7 ) 藤巻竜枝, 岸 澄子, 山口直弘: 喉頭の前癌状 態について。東女医大誌，41：703-711, 1971.

8 ) 小林嘉和子：喉頭角化症 (喉頭前癌状態) の臨 床的ならびに組織学的研究. 日耳鼻, $23: 44-57$, 1977.

9 ）都 南龍，南 仁成，前原法文・他：声帯の白 色病変の臨床的および病理組織学的研究. 日気 食会報, 44：411-418, 1993 .

10）松村祐二郎，中島 格：喉頭癌と dysplasia。 JOHNS， 4：1241-1245, 1988. 